

\title{
THE EFFECT OF SOCIAL ECONOMIC FACTORS ON FARMER BEHAVIOR IN RICE FARMING IN SUMBER KULON VILLAGE, JATITUJUH DISTRICT, MAJALENGKA REGENCY
}

\author{
M. Nasirudin*, W. Sumekar, and T. Dalmiyatun \\ Agribusiness, Faculty of Animal and Agricultural Sciences, Diponegoro University, Semarang, Indonesi \\ Correspondence email: nasirkucai14@gmail.com
}

Submitted 28 February 2020; Accepted 05 August 2020

\begin{abstract}
ABSTRAK
Perilaku petani menandakan seseorang sudah mengetahui pengetahuan, sikap dan keterampilan yang baik dalam kegiatan usahatani padi. tujuan penelitian ini adalah pengaruh faktor sosial ekonomi terhadap perilaku petani dalam usahatani padi. Penelitian ini dilaksanakan pada 21 September - 10 November 2019 di Desa Sumber Kulon Kecamatan Jatitujuh Kabupaten Majalengka, Jawa Barat. Metode yang digunakan dalam penelitian ini adalah survei dengan jumlah responden 240 orang. Teknik pengumpulan data menggunakan kuesioner dan wawancara, sedangkan teknik analisis data menggunakan analisis deskriptif dan analisis regresi linier ganda. Kegiatan patani dalam usahatani padi dimulai dari persiapan lahan, pemilihan bibit padi, persemaian benih padi, penanaman, pemeliharaan, panan dan pasca panen. Hasil penelitian menunjukkan bahwa pengaruh faktor sosial ekonomi terhadap perilaku petani dalam tingkat siginifikasi 0,05 dengan sebesar 0,006, variabel Pendidikan sebesar 0,094, variabel pengalaman sebesar 0,552 , variabel motivasi sebesar 0,034 , variabel penerimaan sebesar 0,096 , variabel media informasi sebesar 0,000 dan varaibel penyuluhan pertanian sebesar 0,010. Hal ini dapat dilihat dari kontribusi petani dalam faktor sosial sebesar $27 \%$ terhadap perilaku petani dikarenakan petani hanya bergantung pada kegiatan usahatani padi. Alasan untuk memilih tetap menjalankan kegiatan ini antara lain sebegai usaha turun-menurut dari keluarga.
\end{abstract}

Kata Kunci: faktor sosial, media, motivasi, padi, penerimaan, perilaku petani

\section{ABSTRACT}

Farmers' behavior indicates someone already knows good knowledge, attitude and skills in rice farming activities. the purpose of this study is the influence of socio-economic factors on the behavior of farmers in rice farming. This research was conducted on 21 September - 10 November 2019 in Sumber Kulon Village, Jatitujuh District, Majalengka Regency, West Java. The method used in this study is a survey with 240 respondents. Data collection techniques using questionnaires and interviews, while data analysis techniques using descriptive analysis and multiple linear regression analysis. Patani activities in rice farming are started from land preparation, selection of rice seeds, rice seedbed, planting, maintenance, food and post-harvest. The results showed that the influence of socio-economic factors on farmer's behavior in the level of siginification was 0.05 with 0.006, Educational variable was 0.094, experience variable was 0.552, motivation variable was 0.034, acceptance variable was 0.096, media information variable was 0,000 and agricultural extension variables were of 0.010. This can be seen from the contribution of farmers in social factors by $27 \%$ of the behavior of farmers because farmers only depend on rice farming activities. The reasons for choosing to keep doing this activity are, among other things, a family business.

Keywords: farmer's behavior, media, motivation, revenue, rice, social factors 


\section{INTRODUCTION}

Paddy is a food crop commodity producing rice that has an essential role in Indonesia's economic life, in which rice as a staple food is very difficult to replace by other staples. Paddy as a food crop is consumed by approximately $90 \%$ of the total population of Indonesia for daily staple food. According to the Central Agency on Statistics of Jatitujuh District, Majalengka Regency (2018) from 27 regencies in West Java, the regencies which become the high rice-producing areas, among other is Majalengka, which was a rice producer of 602,799 tons in 2015. The rice production of the Majalengka Regency is still far from the Indramayu Regency, which reached 1,223,785 tons. The low productivity is because the farmers in Majalengka Regency remain using seeds from the rice harvest and the Sumber Kulon Village in Jatitujuh District is a potential village to develop rice farming.

The Central Agency on Statistics of Jatitujuh District, Majalengka Regency (2018) stated that the area of paddy fields in Jatitujuh District reached 5,680 hectares with rice production reaching 39,480 tons with an average of 55.68 quintals per hectare. Low rice production is due to climatic factors because rice is susceptible to disease attacks and the Sumber Kulon Village still relies on irrigation from rainwater for agriculture. Furthermore, the farming conditions in the Sumber Kulon Village remain poorly, so it is necessary to see the farmer behavior.

Farmer behavior in knowledge in agriculture includes how far farmers understand agriculture. Subsequently, the attitude towards farmer learning is a form of farmer assessment of aspects related to agricultural activities and skills associated with the ability of farmers to perform agricultural activities. The objectives of this research are 1). Describe the socio-economic factors of rice farmers, 2). Analyze farmer behavior in rice farming in the study area, 3). Analyze the effect of socio-economic factors on farmer behavior in rice farming.

\section{RESEARCH METHODS}

The method used in this study was a survey method. It is a research method performed to conduct assessments and measurements of empirical symptoms that take place in the field or research location which is generally performed on the sample unit experienced as respondents and not to the entire target population (Fathoni, 2006).

The research was conducted on 21 October - 10 November 2019 at the association of farmer groups of Sumber Tani in Sumber Kulon Village. The determination of the research area was carried out purposively with particular criteria, which is the location in lowland and having the highest number of farmers in the Jatitujuh District.

The data collection of this study used interviews and questionnaires to obtain information related to socio-economic factors on farmer behavior in rice farming in Sumber Kulon Village, Jatitujuh District, Majalengka Regency.

Determination of the research sample used the simple random sampling method, where the farmer behavior sampled in this study is a combination of farmer groups. The number of farmers in Sumber Kulon Village is 595 farmers. Therefore, to determine the sample from the population in the size of the sample to be used in this study, the Slovin equation was used (Sugiyono, 2009) as shown below:

$\mathrm{n}=\frac{N}{1+N(e) 2}$

$\mathrm{n}=\frac{595}{1+595(0.05) 2}$

$\mathrm{n}=\frac{595}{2.48} \frac{595}{1+100(0.05) 2}$

$\mathrm{n}=239.91$

The sampling technique used simple random sampling with proportional allocation for each farmer group. To determine the sample size for each farmer group, a proportional allocation was carried out so that the sample taken is more proportional. The data obtained from the questionnaire was processed with a Likert scale and then 
classified into the respondent assessment criteria.

The obtained data in the field were processed using tabulation and then analyzed descriptively by presenting the results obtained in the form of a systematic description to obtain complete and detailed results. Data processing for measuring the effect of socio-economic factors on farmer behavior in rice farming used the scoring method. The scoring for each indicator item was 1 to 5 using class interval division. The Nasution and Barizi formulas in Rambe and Honorita (2011) were used. Therefore, class intervals can be determined for each indicator, with the requirement as follows:

$1 \mathrm{NR}=\mathrm{NST}-\mathrm{NSR}$

2 PI $=$ NR : JIK

Notes:

$1 \mathrm{NR}=$ Range Value

2 NST $=$ The Highest Score Value

3 NSR $=$ The Lowest Score Score

$4 \mathrm{PI}=$ Interval Length

5 JIK $=$ Number of Class Intervals

Data analysis for analyzing the effect of the level of knowledge, attitudes, and skills on production used multiple linear regression. Once the data met the classical assumptions, it was then analyzed using the multiple linear regression model. The calculation used the multiple linear regression formula as follows (Ghozali, 2011):

$$
Y=a+b_{1} X_{1}+b_{2} X_{2}+b_{3} X_{3}+e
$$

Notes:

$\mathrm{Y}=$ Farmer Behavior (Rp/MT)

$\mathrm{a}=$ Constant

$\mathrm{b}=$ Regression coefficient

$\mathrm{e}=$ Error

The obtained data were tested using the Kolmogorov-Smirnov model followed by the classic assumption test of multicollinearity, heteroscedasticity, and autocorrelation. If data distribution is normal, then data is analyzed using multiple linear regression. If the opposite or not normally distributed, then Spearman correlation analysis is used (Ghozali, 2011).
The $\mathrm{F}$ test was used to determine the independent and the dependent variable simultaneously. The statistical hypotheses taken were as follows:

$\mathrm{H}_{0}: \mathrm{b}_{1}=\mathrm{b}_{2}=\mathrm{b}_{3}=\mathrm{b}_{4}=\mathrm{b}_{5}=0$

$\mathrm{H}_{1}: \mathrm{b}_{1} \neq \mathrm{b}_{2} \neq \mathrm{b}_{3} \neq \mathrm{b}_{4} \neq \mathrm{b}_{5} \neq 0$

$\mathrm{H}_{0}=$ There is no effect of the independent variables on the dependent variable.

$\mathrm{H}_{1}=$ There is an effect of the independent variables on the dependent variable for at least one independent variable.

The decision-making criteria are as follows:

$\mathrm{H}_{0}$ is rejected and $\mathrm{H}_{1}$ is accepted if $\operatorname{sig}_{\text {hit }} \leq$ 0,05 .

$\mathrm{H}_{1}$ is rejected and $\mathrm{H}_{0}$ accepted if $\operatorname{sig}_{\text {hit }}>0,05$.

The t-test was used to determine the effect of the independent and the dependent variable partially. The statistical hypotheses taken were as follows:

$\mathrm{H}_{0}: \mathrm{b}_{1}=0 ; \mathrm{b}_{2}=0 ; \mathrm{b}_{3}=0 ; \mathrm{b}_{4}=0 ; \mathrm{b}_{5}=0$

$\mathrm{H}_{1}: \mathrm{b}_{1} \neq 0 ; \mathrm{b}_{2} \neq 0 ; \mathrm{b}_{3} \neq 0 ; \mathrm{b}_{4} \neq 0 ; \mathrm{b}_{5} \neq 0$

$\mathrm{H}_{0}=$ There is no effect of the independent variables on 1 dependent variable.

$\mathrm{H}_{1}=$ There is an effect of the independent variables on 1 dependent variable.

follows:

The decision-making criteria is as

$\mathrm{H}_{0}$ is rejected and $\mathrm{H}_{1}$ s accepted if $\operatorname{sig}_{\text {hit }} \leq$ 0,05 .

$\mathrm{H}_{1}$ is rejected and $\mathrm{H}_{0}$ s accepted if $\operatorname{sig}_{\text {hit }}>0,05$.

\section{RESULTS AND DISCUSSION}

\section{Respondent characteristics}

The research respondents were farmers who joined farmer groups. The identity of the respondents was determined based on the productive age of the farmers.

Table 1 shows that the population at the productive age of 15-60 years was 2,390 people. The male population at a productive age was 1,176 people, while the female population at a productive age was 1,214 people. It indicates that the community of Sumber Kulon Village was at a good level at work as employees, traders, and laborers in performing activities, so that they have good 
Table 1. The Number of Inhabitants in the Sumber Kulon Village by Age Group

\begin{tabular}{cccc}
\hline Age (years) & \multicolumn{2}{c}{ Number of People } & Total \\
\cline { 2 - 3 } & Male & Female & \\
\cline { 2 - 3 }$<9$ & 235 & 257 & 492 \\
$11-29$ & 518 & 473 & 991 \\
$30-49$ & 532 & 579 & 1111 \\
$50-69$ & 310 & 339 & 649 \\
$>70$ & 46 & 71 & 117 \\
\hline Total & $\mathbf{1 6 4 1}$ & $\mathbf{1 7 1 9}$ & $\mathbf{3 3 6 0}$ \\
\hline
\end{tabular}

Source: Primary Data Analysis, 2019

potential in performing all activities as stated by some researchers that the productive age of humans is in the range of age $14-55$ years.

\section{Socio-Economic Factors}

The results of the study of internal socio-economic factors are shown in Table 2.

Table 2 shows that the farmers were at a productive age point, in which 234 farmers were 29-62 years old, while 6 people were over 64 years old. The productive age is considered in which a farmer participates fairly in activities held by farmer groups and can carry out farming activities. Law No.13 of 2003 states that the productive workforce is 15-64 years old. According to BAP'PENAS (2013), the number of people of productive age (15-64 years) is greater than the number of non-productive age ( $<15$ and $>64$ years).

Table 2 shows that most of the farmers' education level was at the 1-6-year level. This education level has an effect on the knowledge of farmers in receiving information and innovation in rice farming management as the main job in the Sumber Kulon Village. The low level of education of the farmers was due to the limited financial plan of the people in the past in taking education. According to Dimyanti and Majiono (2009), education is a strong and consistent predator of a person's attitudes, values, and behavior for the future.

Table 2 shows that the farmers had experience in running rice farming activities with categories exceeding 10 years. Farmers are considered to be experienced when they can solve a problem in dealing with their farming or in farmer group activities. Farming experience is divided into 3 categories, including less experienced $(<5$ years $)$, moderately experienced (5-10 years), and experienced ( $>10$ years). The farmers in Sumber Kulon Village were categorized as experienced because they have $>10$ years of experience. It is in accordance with Suparno (2001) who stated that experience is the possession of knowledge experienced by a person in an indefinite period.

Table 2 shows that the Motivation Needs of farmers towards rice farming as social needs had a percentage of $50 \%$. The motivation of farmers as physiological/basic needs was that farmers carry out rice farming activities as inheritance and as their primary job and to achieve life satisfaction in meeting food needs in their families. This is in accordance with the argument of Winardi (2001) that motivation is a potential force that exists within human beings that can be developed by themselves or developed by some external forces.

Table 2 shows that the farmer revenue was $31.3 \%$. Some of the revenue from farming were used for household consumption and some are given to middlemen. Household needs of food were considered fulfilled and farmers' needs of clothing could be considered that some farmers had fulfilled the needs of their families according to their harvest yields. The farmers' revenue with the area of land owned by farmers was at least IDR. 2,850,000 per season and the highest revenue from farming activities was Rp. 176,700,000 per season. 
Table 2. Number of Respondents Based on Age, Education, Experience, Motivation and Acceptance

\begin{tabular}{|c|c|c|c|}
\hline Variable & Measurement & $\begin{array}{c}\text { Number of } \\
\text { Respondents }\end{array}$ & Percentage $(\%)$ \\
\hline \multirow[t]{3}{*}{ Age } & $29-37$ & 9 & 3,8 \\
\hline & $38-52$ & 163 & 67,9 \\
\hline & $53-67$ & 68 & 28,3 \\
\hline Total & & 240 & 100 \\
\hline \multirow[t]{5}{*}{ Education } & No School & 0 & 0 \\
\hline & $1-6$ & 174 & 72,5 \\
\hline & $7-9$ & 52 & 21,7 \\
\hline & $10-12$ & 11 & 4,6 \\
\hline & $>12$ & 3 & 1,3 \\
\hline Total & & 240 & 100 \\
\hline \multirow[t]{3}{*}{ Experience } & $<10$ & 14 & 5,8 \\
\hline & $11-20$ & 111 & 46,3 \\
\hline & $>21$ & 115 & 47,9 \\
\hline Total & & 240 & 100 \\
\hline \multirow[t]{5}{*}{ Motivation } & Actualization & 0 & 0 \\
\hline & Pride & 0 & 6 \\
\hline & Social & 120 & 50 \\
\hline & Sense of secure & 120 & 50 \\
\hline & Physiological & 0 & 0 \\
\hline Total & & 240 & 100 \\
\hline \multirow[t]{5}{*}{ Revenue } & Rp. 100.000-Rp. 5.000.000 & 16 & 6,7 \\
\hline & Rp. 5.100.000-Rp.10.000.000 & 70 & 29,2 \\
\hline & Rp. 10.100.000-Rp. 20.000 .000 & 75 & 31,3 \\
\hline & Rp. 20.100.000-Rp. 30.000 .000 & 32 & 13,3 \\
\hline & $>\mathrm{Rp} 30.100 .000$ & 47 & 19,6 \\
\hline Total & & 240 & 100 \\
\hline
\end{tabular}

Source: Primary Data Analysis, 2019

This was in accordance with the argument of Soekartawi et al., (2011) that the concepts of revenue, cost, and income are closely related to farm performance.

Research results of external socio-economic factors are shown in Table 3.

Table 3 shows that farmers in utilizing information media were classified as good with a percentage of $54.2 \%$. Farmers used electronic media and printed media as information in running rice farming. They who could obtain information every day are considered to be very good farmers, while those who obtain information every 2 days are considered to be good farmers, and those who obtain information every 3 days are classified as moderate. This is in accordance with Isbandi (2008) who stated that information media is a tool or medium of introduction from a party to be conveyed to another.

Table 3 shows the agricultural advisory services. Most of the respondents were classified as frequent with a percentage of $67.5 \%$. The results of the study show that agricultural advisory services were classified as frequent because farmers were active in participating in activities held by advisory services agents in Sumber Kulon Village. The meetings of advisory services with farmers were held regularly every 2 months. Apart from regular meetings with agricultural advisory services agents, when the farmers faced a problem in the field, they could report 
Tabel 3. Number of Respondents Based on Information Media and Agricultural Extension

\begin{tabular}{lccc}
\hline \multicolumn{1}{c}{ Variable } & Measurement & $\begin{array}{c}\text { Number of } \\
\text { Respondents }\end{array}$ & Percentage (\%) \\
\hline Media Information & Very rarely & 0 & 0 \\
& Rarely & 0 & 0 \\
& Enough & 110 & 45,8 \\
& Good & 130 & 54,2 \\
Total & Very good & 0 & 0 \\
\hline Agriculture Extension & Very rarely & $\mathbf{2 4 0}$ & $\mathbf{1 0 0}$ \\
Officer & & 0 & 0 \\
& Rarely & 11 & 4,5 \\
& Enough & 37 & 15,5 \\
& Often & 162 & 67,5 \\
Total & Very often & 30 & 12,5 \\
\hline
\end{tabular}

Source: Primary Data Analysis, 2019

to the advisory services agents. In 2-3 days, advisory services agents come to see the problem and provide solutions to the problem. According to Najib and Rahwita (2010), the implementation of advisory services that is held by advisory services agents 2 times a month is considered by farmers to be very optimal. In guiding, farmers feel that the advisory services agents are competent in providing opinions/ideas on the problems.

\section{The Effect of Socio-Economic Factors on} Farmer Behavior

Based on the results of multiple linear regression analysis, the results are shown in Table 4 as follows:

Based on Table 4, the effect of socioeconomic factors on farmer behavior in rice farming in Sumber Kulon Village, Jatitujuh District, Majalengka Regency is as follows: The value coefficient of determination $\left(\mathrm{R}^{2}\right)$ is 0.278 or $27.8 \%$, indicating that the effect of socio-economic factors on farmer behavior in rice farming is $27.8 \%$, while the remaining

Table 4. Multiple Linear Regression Results

\begin{tabular}{clccc}
\hline No & \multicolumn{1}{c}{ Independent variable } & Betta & T-Value & Sig. \\
\hline 1 & Age $\left(\mathrm{X}_{1}\right)$ & 2.456 & 2.791 & 0.006 \\
2 & Education $\left(\mathrm{X}_{2}\right)$ & 4.192 & 1.680 & 0.094 \\
3 & Knowledge $\left(\mathrm{X}_{3}\right)$ & 0.793 & 0.596 & 0.552 \\
4 & Motivation $\left(\mathrm{X}_{4}\right)$ & 2.543 & 2.127 & 0.034 \\
5 & Revenue $\left(\mathrm{X}_{5}\right)$ & 2.516 & 1.674 & 0.096 \\
6 & Information media $\left(\mathrm{X}_{6}\right)$ & 3.464 & 3.745 & 0.000 \\
7 & Agricultural extension officer $\left(\mathrm{X}_{7}\right)$ & 1.799 & 2.604 & 0.010 \\
& Dependent variable & $:$ Farmer Behavior & & \\
& Constant & $: 159.509$ & & \\
& R square $\left(\mathrm{R}^{2}\right)$ & $: 0,278$ & & \\
& F-Value & $: 14,141$ & & \\
& Sig. & $: 0,200$ & & \\
\hline
\end{tabular}

Information: *) Significance at $\alpha(5 \%)$

Source: Primary Data Analysis, 2019 
$72.2 \%$ farmer behavior is affected by other variables not examined in this study.

The $\mathrm{F}$ test results obtained a significant value of 14,144 with a significance of 0,000 . The value of $F_{\text {count }}$ is 14.141 which is greater than $\mathrm{F}_{\text {table }}$ of 2.05 and significant $\mathrm{a}=$ $5 \%(0.05)$, indicating that $\mathrm{H}_{\mathrm{a}}$ is accepted and $\mathrm{H}_{0}$ is rejected. It means that simultaneously, the variables of age, education, experience, motivation, revenue, information media, and agricultural advisory services have a significant effect on the variable of farmer behavior in farming so that the regression model can be used to predict the effect of the seven variables that have been stated above. This is in accordance with Sadono (2008) who stated that positive behavior indicates that a person already knows good knowledge, attitudes, and skills in performing agricultural activities.

a Age of the farmers

The results of the partial test analysis show that age has an effect on farmer behavior. Productive farmers can perform farming activities. The effect of age on behavior is that farmers are actively involved in activities held by farmer groups such as training in rice farming and interacting with farmers in planning their farming activities. It is in accordance with Hasyim (2006) who stated that the age of farmers greatly affects physical knowledge and responds to new aspects in running the farming.

b Education of the farmers

The results of the partial test analysis show that education has no effect on farmer behavior. The education level of farmers is at the level of 1-6 years (Elementary School) resulting in weakness in receiving information in farming knowledge. Factors that have an impact on farmer behavior, which is the decision to select seeds, which on average use local seeds from previous harvests, which do not necessarily meet the requirements and guarantees from the government. According to Dimyanti and Majiono (2009), education is a strong and consistent predator of a person's attitudes, values, behavior for the future.

c Farming experience

The results of the analysis of the partial test show that experience has no effect on farmer behavior. The experience of the farmers running agricultural activities has exceeded 10 years where this figure is stated as experienced farmers. Experienced farmers can face farming problems in overcoming pests and diseases, have skills in using agricultural tools, and behavior in using pesticides at doses recommended by the advisory services. It is in accordance with the argument of Kusuma (2006) who stated that farmers who have been farming for a longer period will find it easier to apply advisory services advice than novice farmers because they have more experience so they can make comparisons in making decisions.

d The motivation of the farmers

The results of the partial test analysis show that motivation has an effect on farmer behavior. The motivation felt by farmers on farmer behavior from the basic/physiological needs of the farmers is shown by the attitude of choosing farming which is a motivation to fulfill their daily needs. The need for farmer security is obtained from a source of knowledge from the experience of farmers who have been running for years and farmers with the motivation of the social needs of farmers will get farming skills and activities from other farmers in an activity of exchanging ideas in managing agricultural land. This is in accordance with Winardi (2001) who stated that motivation is a potential force that exists in human beings that can be developed by themselves or be developed by some external forces.

e Farmer revenue

The results of the partial test analysis show that revenue has no effect on farmer behavior. Revenue will have an effect on the area of land owned, where the revenue of the farmers' income is used to meet the needs of their families, thereby reducing 
the production capital for the harvest for the future planting period. In responding to the low selling price in the rainy season, which causes the price to fall, farmers have to look for some additional jobs. This is in accordance with the argument of Sundari (2011) who stated that farmer revenue is affected by several factors, including farm area, production amount, type, and price of farmed commodities.

f Information media

The results of the partial test analysis show that information media has an effect on farmer behavior. Farmers make good use of electronic media and print media where they access the internet such as YouTube to find information on current agricultural innovation and technology. It can be seen in the farmer behavior where they have used a rice thresher which is more efficient and their attitude in choosing types of pesticides in preventing pests and diseases. It is in accordance with the argument of Laura (2002) who stated that video as an instructional medium can show the way to use a product step by step and simultaneously evoke feelings and attract interest to change behavior.

g Agricultural advisory services

The results of the partial test analysis show that agricultural advisory services have an effect on farmer behavior. Farmers in the village are active in activities held by farmer groups, showing behavior that farmers are active in seeking knowledge in training activities for rice farming in the success of their farming and attitudes in using straw as organic fertilizer by burning it obtained from the advisory services. It is in accordance with the argument of Mufriantie and Feriady (2014) that one of the efforts to increase farmers' knowledge is obtained through advisory services, sharing, and social media activities.

\section{CONCLUSIONS}

The results show that 1). Rice farmers in Sumber Kulon Village are classified as farmers of productive age, socially classified as low but economically classified as medium. Sources of information about rice farming were obtained from information media $(54.2 \%)$ and agricultural advisory services $(67.5 \%) 2)$. The farmer behavior of rice farmers in Sumber Kulon Village in rice farming is quite good $(60.4 \%)$ where the level of farmer knowledge is $68.3 \%$, the attitude of the farmer is $85.8 \%$, and the skill is $43.3 \%$. $3)$. Factors that significantly affect farmer behavior in rice farming are age, motivation, media information, and agricultural advisory services. Meanwhile, factors that have no effect on farmer behavior in rice farming are education, experience, and revenue. Recommendations for the nest is:

1.1 Farmers need to consider using seeds planted in the rainy season, that are resistant to weather such as floods and winds which is pari kebo with thick stems and are resistant to weather.

1.2 For rice farming not to be a routine or habitual business, the material needed to be informed should be completed with material on rice agro-industry which has high added value.

\section{REFERENCES}

Central Agency on Statistics of Jatitujuh District, Majalengka Regency. 2018. Kecamatan Jatitujuh dalam angka 2018. BPS: Majalengka.

Dimyanti and Mudjiono, 2009. Belajar dan pembelajaran. Jakarta: Rineka Cipta.

Fathoni, A. 2006. Metodologi penelitian \& teknik penyusunan skripsi. Jakarta: PT. Rineke Cipta.

Mufriantioe, F., and A. Feriady. 2014. Analisis faktor produksi dan efisiensi alokatif usahatani bayam (Amarathus $S p$ ) di Kota Bengkulu. Jurnal Agrisep 15(1): 31-37.

Ghozali, I. 2011. Aplikasi analisis multivariate dengan program SPSS. Semarang: UNDIP Press. 
Hasyim, H. 2006. Analisis hubungan faktor sosial ekonomi petani terhadap program penyuluhan pertanian. Penelitian LP Universitas Sumatera Utara, Medan.

Isbandi. A. R. 2008. Intervensi komunitas: Pengembangan masyarakat sebagai upaya pemberdayaan masyarakat. Jakarta: Rajawali Press.

Kusuma, H. 2006. Manajemen produksi: Perencanaan dan pengendalian produksi. Yogyakarta: BPFE.

Laura, B. 2002. Elemen desain teks dan pesan dan dampaknya pada keterbacaan pesan: tinjauan sastra. Jurnal Desain Komunikasi. Sekolah Pengemasan, Universitas Negeri Michigan.

Najib, M., and H. Rahwita. 2010. Peran penyuluhan petani dalam pengembangan kelompok tani di Desa Bukit Raya Kecamatan Tenggarong. Jurnal Ziraa'ah 28: 116-127.

Rambe, S. S. M., and B. Honorita. 2011. Perilaku petani dalam usahatani di lahan rawa lebak. Prosiding Seminar Nasional Budidaya Pertanian 2(1): 115128.

Sadono, D. 2008. Pemberdayaan petani: Paradigma baru penyuluhan pertanian di Indonesia. Jurnal Penyuluhan 4(1): 65-74.

Soekartawi, A. Soeharjo, J. L. Dillon, J. B. Hardaker. 2011. Ilmu usahatani dan penelitian untuk pengembangan petani kecil. Jakarta: UI-Press.

Sugiyono. 2009. Metode penelitian pendidikan pendekatan kuantitatif, kualitatif, dan R\&D. Bandung: Alfabeta.

Sundari, M. T. 2011. Analisis dan pendapatan usahatani wortel di Kabupaten Karanganyar. Jurnal SEPA 7(2): 119126.

Suparno, S. 2001. Membangun kompetensi belajar. Jakarta: Direktorat Jenderal Pendidikan Tinggi. Departemen Pendidikan Nasional.
Winardi. 2001. Motivasi dan pemotivasian dalam manajemen. Jakarta: PT. Raja Grafindo. 